Pathophysiology

of Haemostasis

and Thrombosis

\title{
Complications of Hydroxyethyl Starch in Acute Ischemic Stroke and Other Brain Injuries
}

\author{
Christian J. Wiedermann \\ 2nd Division of Internal Medicine, Department of Internal Medicine, Central Hospital of Bolzano, Bolzano, Italy
}

\author{
Key Words \\ Hydroxyethyl starch - Acute ischemic stroke - Brain \\ injuries · Complications, hydroxyethyl starch · Safety, \\ hydroxyethyl starch · Hemorrhages - Blood coagulation \\ disorders · Mortality, brain injuries
}

\begin{abstract}
Serious complications of hydroxyethyl starch (HES) administration have been repeatedly demonstrated in clinical trials of acute ischemic stroke and other brain injuries. Such complications have prompted the premature termination of several randomized trials. Coagulopathy and bleeding have been the most frequently documented complications in the brain injury setting and have occurred after exposure to HES solutions of widely varying molecular weight and substitutions. Severe, protracted, refractory pruritus is another HES complication. Claims of safety for HES solutions have often been made on the basis of small trials with inadequate statistical power. Additionally, the safety has been typically assessed in highly selected low-risk patient populations receiving relatively small HES doses, so that the results cannot be generalized to routine clinical practice. The
\end{abstract}

preponderance of available evidence suggests that HES solutions should be avoided in acute ischemic stroke and other brain injuries.

Copyright $@ 2004$ S. Karger AG, Basel

\section{Introduction}

In their recent report of a randomized trial on the use of hydroxyethyl starch (HES) with a molecular weight of 130 $\mathrm{kDa}$ and substitution of 0.4 (HES 130/0.4) in 40 patients with acute ischemic stroke, Woessner et al. [1] concluded that 'HES 130/0.4, even when infused in large quantities, has a high degree of therapeutic safety'. As this conclusion is unjustified for several reasons, an in-depth discussion of the use of HES in patients with acute ischemic stroke is presented. Copious prior evidence indicates serious safety problems of HES [2], especially when used in acute ischemic stroke and other brain injuries [3-15], as summarized in table 1. The trial of Woessner et al. [1] was not powered to assess safety adequately, and key safety data from the trial were not reported. Furthermore, a highly selected, low-risk patient population was enrolled, so that the results of the trial cannot be generalized to routine clinical practice.

\section{KARGER \\ Fax +4161306 1234 \\ E-Mail karger@karger.ch \\ www. karger.com

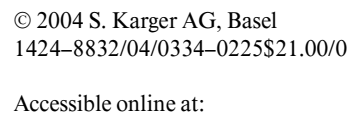

Christian J. Wiedermann, MD

Seconda Medicina, Ospedale Centrale di Bolzano

Via Lorenzo Böhler 5

IT-39100 Bolzano (Italy)

Tel. +390471 908190, Fax +390471 908303, E-Mail christian.wiedermann@asbz.it 
Table 1. HES complications in patients with acute ischemic stroke and other brain injuries

\begin{tabular}{|c|c|c|c|}
\hline $\begin{array}{l}\text { Study } \\
\text { (year of publication) }\end{array}$ & Design & Fluid regimen & Complications \\
\hline $\begin{array}{l}\text { Toole [3] } \\
(1987)\end{array}$ & Pharmacovigilance study & HES 450/0.7 & $\begin{array}{l}\text { Bleeding in } 8 \text { neurosurgical patients treated with } \\
\text { HES; manufacturer recommendation issued against } \\
\text { HES for cerebral vasospasm after SAH or other } \\
\text { conditions requiring repeated use over several days }\end{array}$ \\
\hline $\begin{array}{l}\text { Hemodilution in Stroke } \\
\text { Study Group [4] } \\
\text { (1989) }\end{array}$ & $\begin{array}{l}\text { Multicenter randomized trial of } \\
88 \text { acute ischemic stroke } \\
\text { patients }\end{array}$ & $\begin{array}{l}\text { Hypervolemic hemodilution with HES } \\
200 / 0.5 \text { vs. standard therapy } 24 \mathrm{~h} \text { after } \\
\text { onset }\end{array}$ & $\begin{array}{l}\text { Trial stopped prematurely because of significantly } \\
\text { increased mortality related to cerebral edema in } \\
\text { recipients of HES }\end{array}$ \\
\hline $\begin{array}{l}\text { Mast and Marx [5] } \\
\text { (1991) }\end{array}$ & $\begin{array}{l}\text { Randomized trial of } 70 \text { acute } \\
\text { ischemic stroke patients }\end{array}$ & $\begin{array}{l}\text { Isovolemic hemodilution with } 10 \% \\
\text { HES } 200 / 0.5 \text { vs. no hemodilution }\end{array}$ & $\begin{array}{l}\text { Trial discontinued due to clinical deterioration in } \\
8 \text { HES recipients vs. none of the control group } \\
\text { patients }(\mathrm{p}<0.01)\end{array}$ \\
\hline $\begin{array}{l}\text { Treib et al. [6] } \\
\text { (1995) }\end{array}$ & $\begin{array}{l}\text { Nonrandomized controlled trial } \\
\text { of } 20 \text { patients with cerebral } \\
\text { circulatory disturbances } \\
\text { without evidence of cardiac or } \\
\text { renal insufficiency }\end{array}$ & $\begin{array}{l}500 \mathrm{ml} 10 \% \mathrm{HES} 200 / 0.5 \text { with a C2/C6 } \\
\text { ratio of } 13.4 \text { vs. } 5.7 \text { followed by } \\
1,000 \mathrm{ml} \text { later on } 1 \mathrm{st} \text { day, } 1,000 \mathrm{ml} / \text { day } \\
\text { on days } 2-4 \text {, and } 500 \mathrm{ml} / \text { day on days } \\
5-10\end{array}$ & $\begin{array}{l}\text { aPTT prolonged and factor VIII:C and vWF:Ag } \\
\text { decreased in both groups throughout the } 10 \text {-day } \\
\text { study period }(\mathrm{p}<0.05) \text {; effects greater for } 13.4 \mathrm{C} 2 / \\
\mathrm{C} 6 \text { group }(\mathrm{p}<0.05) \text {; vWF:RC reduced in } 13.4 \text { but } \\
\text { not } 5.7 \mathrm{C} 2 / \mathrm{C} 6 \text { group }(\mathrm{p}<0.01)\end{array}$ \\
\hline $\begin{array}{l}\text { Trumble et al. [7] } \\
\text { (1995) }\end{array}$ & $\begin{array}{l}\text { Nonrandomized controlled trial } \\
\text { of } 85 \text { patients with cerebral } \\
\text { vasospasm after SAH }\end{array}$ & $\begin{array}{l}6 \% \text { HES } 450 / 0.7 \text { vs. } 5 \% \text { albumin } \\
\text { (plasma protein fraction) }\end{array}$ & $\begin{array}{l}\text { HES infusion prolonged partial thromboplastin } \\
\text { time }(\mathrm{p}<0.001) ; 4 \text { HES recipients required trans- } \\
\text { fusion, } 1 \text { patient underwent re-exploration for } \\
\text { bleeding, and } 1 \text { patient developed a delayed post- } \\
\text { operative epidural hematoma necessitating } \\
\text { evacuation }\end{array}$ \\
\hline $\begin{array}{l}\text { Treib et al. [8] } \\
\text { (1996) }\end{array}$ & $\begin{array}{l}\text { Randomized trial of } 20 \text { patients } \\
\text { with cerebrovascular diseases }\end{array}$ & $\begin{array}{l}1,500 \mathrm{ml} 10 \% \mathrm{HES} 200 / 0.5 \text { vs. } 6 \% \mathrm{HES} \\
40 / 0.5 \text { on day } 1,1,000 \mathrm{ml} / \text { day on days } \\
2-4 \text {, and } 500 \mathrm{ml} / \text { day on days } 5-10\end{array}$ & $\begin{array}{l}\text { Platelet number and volume declined in both } \\
\text { groups during the 1st day of HES therapy } \\
(\mathrm{p}<0.05) \text {; no significant differences in platelet } \\
\text { aggregation }\end{array}$ \\
\hline $\begin{array}{l}\text { Treib et al. [9] } \\
\text { (1996) }\end{array}$ & $\begin{array}{l}\text { Nonrandomized controlled trial } \\
\text { of } 30 \text { patients with cerebro- } \\
\text { vascular diseases }\end{array}$ & $\begin{array}{l}1,500 \mathrm{ml} 6 \% \text { HES } 200 / 0.62 \text { vs. } 10 \% \\
\text { HES } 200 / 0.5 \mathrm{vs.} 6 \% \text { HES } 40 / 0.50-0.55 \\
\text { on day } 1,1,000 \mathrm{ml} / \text { day on days } 2-4 \text {, } \\
\text { and } 500 \mathrm{ml} / \text { day on days } 5-10\end{array}$ & $\begin{array}{l}\text { Platelet number and volume declined in all groups } \\
\text { during the } 1 \text { st day of HES therapy }(\mathrm{p}<0.05) \text {; the } \\
\text { platelet volume reduction persisted throughout the } \\
\text { 10-day observation period in all groups }(\mathrm{p}<0.05)\end{array}$ \\
\hline $\begin{array}{l}\text { Stoll et al. [10] } \\
\text { (1997) }\end{array}$ & $\begin{array}{l}\text { Cohort of } 10 \text { patients with } \\
\text { acute infarction in the middle } \\
\text { cerebral artery region }\end{array}$ & $\begin{array}{l}3,000 \mathrm{ml} 6 \% \mathrm{HES} 70 / 0.5 \text { on } 1 \text { st day and } \\
1,500 \mathrm{ml} \text { on days } 2-4\end{array}$ & aPTT prolonged $(\mathrm{p}<0.05)$ \\
\hline $\begin{array}{l}\text { Treib et al. [11] } \\
\text { (1997) }\end{array}$ & $\begin{array}{l}\text { Cohort of } 10 \text { patients with } \\
\text { stroke or transient ischemic } \\
\text { attack }\end{array}$ & $\begin{array}{l}\text { Loading dose of } 500 \mathrm{ml} 10 \% \text { HES 200/ } \\
0.62 \text { followed by } 500 \mathrm{ml} \text { maintenance } \\
\text { dose per day for } 10 \text { days }\end{array}$ & $\begin{array}{l}\text { aPTT prolonged by } 43 \%(\mathrm{p}<0.01) \text {; factor VIII:C, } \\
\text { vWF:RC, and } \mathrm{vWF} \text { :Ag reduced to values }<30 \% \\
\text { ( } \mathrm{p}<0.01 \text { for all comparisons) }\end{array}$ \\
\hline $\begin{array}{l}\text { Jonville-Béra et al. [12] } \\
\text { (2001) }\end{array}$ & $\begin{array}{l}\text { Pharmacovigilance study of } \\
\text { adverse events spontaneously } \\
\text { reported to } 31 \text { French regional } \\
\text { drug-monitoring centers during } \\
\text { 1990-1997 }\end{array}$ & $\begin{array}{l}\text { HES } 200 / 0.5 \text { as hemodilution therapy } \\
\text { for vasospasm secondary to SAH }\end{array}$ & $\begin{array}{l}\text { Nine cases reported of acquired type I von Wille- } \\
\text { brand's disease associated with HES, including } \\
4 \text { cases complicated by cerebral hemorrhage and } \\
1 \text { by extradural hematoma; } 3 \text { of } 4 \text { cerebral hemor- } \\
\text { rhage cases fatal }\end{array}$ \\
\hline $\begin{array}{l}\text { Kimme et al. [13] } \\
(2001)\end{array}$ & Cohort of $50 \mathrm{SAH}$ patients & Hemodilution with HES & $\begin{array}{l}\text { Delayed pruritus manifested as pruritic crises in } \\
54 \% \text { of the patients; pruritus persisted for a mean } \\
\text { duration of } 15 \text { weeks }\end{array}$ \\
\hline $\begin{array}{l}\text { Rudolf }[14] \\
(2002)\end{array}$ & $\begin{array}{l}\text { Randomized phase II safety } \\
\text { study in } 106 \text { acute ischemic } \\
\text { stroke patients }\end{array}$ & $\begin{array}{l}\text { Hypervolemic hemodilution with } 10 \% \\
\text { HES } 130 / 0.4 \text { vs. } 0.9 \% \text { saline }\end{array}$ & $\begin{array}{l}\text { Serious cerebrovascular adverse events in } 5.7 \% \text { of } \\
\text { the HES } 130 / 0.4 \text { vs. } 2.8 \% \text { of the saline recipients }\end{array}$ \\
\hline $\begin{array}{l}\text { Neff et al. [15] } \\
(2003)\end{array}$ & $\begin{array}{l}\text { Randomized trial of } 31 \text { cranio- } \\
\text { cerebral trauma patients }\end{array}$ & $\begin{array}{l}\leq 70 \mathrm{ml} \cdot \mathrm{kg}^{-1} \cdot \mathrm{day}^{-1} \mathrm{HES} 130 / 0.4 \mathrm{vs} \\
\leq 33 \mathrm{ml} \cdot \mathrm{kg}^{-1} \cdot \mathrm{day}^{-1} \mathrm{HES} 200 / 0.5 \text { for } \\
\text { up to } 28 \text { days }\end{array}$ & $\begin{array}{l}\text { Trial prematurely halted due to a high incidence of } \\
\text { intracranial bleeding complications in both HES } \\
130 / 0.4(31 \%) \text { and HES 200/0.5 (33\%) recipients }\end{array}$ \\
\hline
\end{tabular}

HES = Hydroxyethyl starch; SAH = subarachnoid hemorrhage; $\mathrm{aPTT}=$ activated partial thromboplastin time; $\mathrm{vWF}=$ von Willebrand factor; RC = ristocetin cofactor. 


\section{HES in Acute Ischemic Stroke}

Dramatizing the risks of HES in patients with acute ischemic stroke and other brain injuries has been the discontinuation of three randomized trials due to excess mortality [4], clinical deterioration [5], or intracranial bleeding complications [15] among HES recipients. Coagulopathy and hemorrhage have been the most frequently described complications of HES in the brain injury setting (table 1). Such complications have been encountered with HES solutions across the entire spectrum of molecular weights and substitutions, including HES 40/0.5, HES 70/ 0.5, HES 130/0.4, HES 200/0.5, HES 200/0.62, and HES 450/0.7 (table 1).

Another common HES complication is severe, prolonged refractory pruritus of delayed onset [13]. In the trial of Woessner et al. [1], pruritus occurred in 3 of 20 patients in the HES 130/0.4 group and in 2 of 20 crystalloid recipients. Thus, the incidence of pruritus was $50 \%$ higher in the patients exposed to HES 130/0.4. Although this difference was not statistically significant, the observed statistical power of the trial to detect a significant difference of this magnitude by Fisher's exact test was only $2.9 \%$. The sample size for the trial was intended to afford $80 \%$ power. Safety claims for HES based on small, underpowered trials have been criticized [16]. Another example was a trial in acute ischemic stroke patients [14], in which the incidence of serious cerebrovascular events was twice as high in the HES 130/0.4 group (5.7\%) as in the patients receiving saline (2.8\%). Again, the difference was not significant, but the observed power to demonstrate such a difference was only $1.7 \%$.

In the trial of Woessner et al. [1], essential data were omitted. Though recognizing that bleeding complications are 'a much feared side effect' of HES, Woessner et al [1] provided no data on such complications or on any other adverse events except pruritus. They assessed hemostatic function by measuring platelets, prothrombin time, activated partial thromboplastin time, fibronectin, factor VIII:C, von Willebrand factor antigen, and von Willebrand ristocetin cofactor; however, they did not report the results of these measurements.

Patients with mild stroke (mean Barthel index score $>90$ ) entered the trial performed by Woessner et al. [1]. Exclusion criteria were intracranial hemorrhage, aphasia, cardiac insufficiency, coagulation disorders, trauma, blood loss, renal insufficiency, and treatment with thrombolytic medication. Thus, the underlying risk of complications in the trial population was low. Furthermore, contrary to the characterization by the authors, the HES 130/ 0.4 dose administered (mean 1,625 ml/day for 4 days) was not high as compared, e.g., with that in another recent brain injury trial [15], in which the HES 130/0.4 dose averaged $2,300 \mathrm{ml} /$ day for a mean of 6.6 days.

\section{Conclusions}

The trial performed by Woessner et al. [1] 'shows that the newly developed 6\% HES 130/0.4 is a safe drug'. Such an endorsement of HES 130/0.4 safety cannot be accepted due to the limitations of the trial. A more cautious conclusion would appear to be particularly warranted in the light of the disclosure that the manufacturer of HES 130/0.4 funded the study, defrayed the costs for the study medication, data analysis, insurance, and the ethics committee, and contributed to the research fund of the clinic at which the trial was conducted. Indeed, if all the currently available evidence is considered, there appears to be greater support for the conclusion that HES solutions are not safe in acute ischemic stroke and other brain injuries.

\section{References}

1 Woessner R, Grauer MT, Dieterich HJ, Bepperling F, Baus D, Kahles T, Georgi S, Bianchi $\mathrm{O}$, Morgenthaler M, Treib J: Influence of a long-term, high-dose volume therapy with $6 \%$ hydroxyethyl starch 130/0.4 or crystalloid solution on hemodynamics, rheology and hemostasis in patients with acute ischemic stroke: Results of a randomized, placebo-controlled, double-blind study. Pathophysiol Haemost Thromb 2003:33:121-126.
2 Barron ME, Wilkes MM, Navickis RJ: A systematic review of the comparative safety of colloids. Arch Surg 2004;139:552-563.

3 Toole JG: Hetastarch in cerebral vasospasm. J Neurosurg 1987;66:636-637.

4 Hemodilution in Stroke Study Group: Hypervolemic hemodilution treatment of acute stroke: Results of a randomized multicenter trial using pentastarch. Stroke 1989;20:317323.

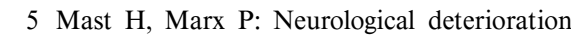
under isovolemic hemodilution with hydroxyethyl starch in acute cerebral ischemia. Stroke 1991;22:680-683.

-6 Treib J, Haass A, Pindur G, Seyfert UT, Treib W, Grauer MT, Jung F, Wenzel E, Schimrigk K: HES 200/0.5 is not HES 200/0.5: Influence of the $\mathrm{C} 2 / \mathrm{C} 6$ hydroxyethylation ratio of hydroxyethyl starch (HES) on hemorheology, coagulation and elimination kinetics. Thromb Haemost 1995;74:1452-1456. 
7 Trumble ER, Muizelaar JP, Myseros JS, Choi SC, Warren BB: Coagulopathy with the use of hetastarch in the treatment of vasospasm. J Neurosurg 1995;82:44-47.

$>8$ Treib J, Haass A, Pindur G, Grauer MT, Treib W, Wenzel E, Schimrigk K: Influence of low and medium molecular weight hydroxyethyl starch on platelets during a long-term hemodilution in patients with cerebrovascular diseases. Arzneimittelforschung 1996;46:10641066.

$>9$ Treib J, Haass A, Pindur G, Treib W, Wenzel E, Schimrigk K: Influence of intravascular molecular weight of hydroxyethyl starch on platelets. Eur J Haematol 1996;56:168-172.
10 Stoll M, Treib J, Schenk JF, Windisch F, Haass A, Wenzel E, Schimrigk K: No coagulation disorders under high-dose volume therapy with low-molecular-weight hydroxyethyl starch. Haemostasis 1997;27:251-258.

11 Treib J, Haass A, Pindur G, Grauer MT, Jung F, Wenzel E, Schimrigk K: Increased haemorrhagic risk after repeated infusion of highly substituted medium molecular weight hydroxyethyl starch. Arzneimittelforschung 1997;47:18-22.

12 Jonville-Béra AP, Autret-Leca E, Gruel Y: Acquired type I von Willebrand's disease associated with highly substituted hydroxyethyl starch. N Engl J Med 2001;345:622-623.

13 Kimme P, Jannsen B, Ledin T, Gupta A, Vegfors $\mathrm{M}$ : High incidence of pruritus after large doses of hydroxyethyl starch (HES) infusions. Acta Anaesthesiol Scand 2001;45:686-689.
4 Rudolf J: Hydroxyethyl starch for hypervolemic hemodilution in patients with acute ischemic stroke: A randomized, placebo-controlled phase II safety study. Cerebrovasc Dis 2002;14: 33-41.

15 Neff TA, Doelberg M, Jungheinrich C, Sauerland A, Spahn DR, Stocker R: Repetitive largedose infusion of the novel hydroxyethyl starch $130 / 0.4$ in patients with severe head injury. Anesth Analg 2003;96:1453-1459.

16 Winkelmayer WC, Avorn J: Stable creatinine clearance using large-dose HES versus reduced GFR. Kidney Int 2004;65:1111-1112. 